\title{
MODELOWANIE LICZBY TRANSAKCJI DOKONYWANYCH PRZY UŻYCIU GOTÓWKI I KART PŁATNICZYCH NA RYNKU POLSKIM ${ }^{\dagger}$
}

\begin{abstract}
Z a ry s t r e ś c i. W artykule dokonano analizy czynników determinujących intensywność wykorzystania przez polskich klientów trzech głównych metod płatności stosowanych w fizycznych punktach sprzedaży: gotówki, karty debetowej oraz karty kredytowej. Do opisu liczby płatności zastosowano 6 modeli zmiennych licznikowych, między innymi model ujemny dwumianowy i ZINB. Uzyskane wyniki wykazały wpływ wielu czynników demograficznych i ekonomicznych oraz istnienie efektu substytucyjnego. Wykorzystanie kart jest także silnie uzależnione od poczucia bezpieczeństwa oraz preferencji odnośnie anonimowości płatności.
\end{abstract}

S ł o w a k 1 u c z o w e: metody płatności, karty płatnicze, obrót bezgotówkowy, modele zmiennych licznikowych.

\section{WSTĘP}

Artykuł dotyczy problemu wyboru i intensywności wykorzystania przez klientów indywidualnych poszczególnych metod płatności stosowanych $\mathrm{w}$ transakcjach $\mathrm{w}$ fizycznych ${ }^{1}$ punktach sprzedaży. Tematyka ta jest obecnie jednym z podstawowych zagadnień $\mathrm{w}$ ramach badań dotyczących bankowości i systemów płatniczych, co wynika z dużego znaczenia tego problemu dla gospodarki. Prowadzone ostatnio na świecie badania dotyczące kosztów płatności i ich udziału w PKB (Gresvik, Haare, 2009) wykazały, że gotówka jest najdroż-

\footnotetext{
† Praca była finansowana ze środków na naukę w latach 2008-2011 jako projekt badawczy nr N113 308835 Ministerstwa Nauki i Szkolnictwa Wyższego. Autorzy pragną podziękować K. Maciejewskiemu za udział w realizacji badań ankietowych oraz T. P. Wiśniewskiemu za pomocne uwagi i sugestie.

${ }^{1}$ Badania nie obejmują płatności zdalnych dokonywanych $\mathrm{w}$ handlu elektronicznym oraz przekazów pieniężnych i płatności rachunków.
} 
szym instrumentem płatniczym i zmiana struktury dokonywania płatności może przynieść bardzo istotne oszczędności dla gospodarki. W wielu krajach realizowane są szeroko zakrojone programy promowania obrotu bezgotówkowego i zmian zachowań społecznych w zakresie płatności. Jednocześnie powstający właśnie w Europie Jednolity Obszar Płatności w Euro (SEPA) oraz dyrektywa ws. usług płatniczych (PSD) sprawiają że na europejskim rynku płatności detalicznych będą zachodzić w najbliższych latach zasadnicze zmiany. Istnieje zatem bardzo duże zapotrzebowanie na badania wyjaśniające zachowania płatnicze społeczeństwa.

Pierwsze prace, w których podjęto już to zagadnienie stosując zróżnicowaną metodologię, dotyczyły rynku holenderskiego (Bolt i inni, 2008), fińskiego (Leinonen, 2008) oraz amerykańskiego (Borzekowski, Kiser, 2008). Jak dotychczas nie opublikowano jednak żadnych prac dotyczących rynków Europy Srodkowej i Wschodniej, w tym rynku polskiego.

Celem pracy jest poznanie czynników determinujących wykorzystanie metod płatności przez klientów indywidualnych w Polsce. W pracy przyjęto następujące hipotezy badawcze: intensywność wykorzystania poszczególnych metod płatności jest silnie uwarunkowana czynnikami demograficznymi (H1), poczucie bezpieczeństwa oraz problem anonimowości płatności mają istotny wpływ na wykorzystanie kart płatniczych $(\mathrm{H} 2)$, rodzaj punktu handlowego, w którym dokonywana jest płatność, wpływa na intensywność użycia poszczególnych metod płatności (H3).

W pracy przyjęto podejście odmienne od dotychczas stosowanych w literaturze, polegające na badaniu wpływu różnorodnych czynników na liczbę transakcji dokonanych poszczególnymi metodami płatności przez klientów, a nie na ich strukturę. W tym celu zastosowano modele zmiennych licznikowych, które uwzględniają fakt, że liczba transakcji jest nieujemną liczbą całkowitą oraz pozwalają opisać duże zróżnicowanie aktywności płatniczej respondentów. Według wiedzy autorów jest to pierwsze zastosowanie tej metodologii do badania zachowań na rynku płatności detalicznych.

\section{METODY PŁATNOŚCI STOSOWANE W FIZYCZNYCH PUNKTACH SPRZEDAŻY}

Rynek płatności jest przykładem tzw. rynku dwustronnego, na którym konkurują różne platformy technologiczne i biznesowe (Rochet, Tirole, 2003; Chakravorti, Roson, 2006). Muszą one zostać zaakceptowane zarówno przez klientów, jak i handlowców. W rezultacie na rynku metod płatności detalicznych stosowanych w fizycznych punktach sprzedaży funkcjonuje stosunkowo niewiele instrumentów, zwłaszcza $\mathrm{w}$ porównaniu $\mathrm{z}$ rynkiem płatności internetowych (patrz Polasik, Fiszeder, 2009). Wynika to z faktu, że występują na nim silne efekty: sieci i skali (Bolt, Humphrey, 2007), a wprowadzenie nowej metody płatności wymaga poniesienia znacznych nakładów na rozbudowę infrastruktu- 
ry terminali płatniczych (Levitin, 2007). Innowacje w zakresie płatności mobilnych oraz kart bezstykowych i portmonetek elektronicznych rozpowszechniły się jak dotąd tylko w kilku krajach świata, głównie w Azji (Polasik, Maciejewski, 2009). W rezultacie jako powszechnie akceptowane środki płatności do dyspozycji klientów pozostają: (1) pieniądz gotówkowy oraz karty płatnicze, które ze względu na funkcjonalność i dostępność ${ }^{2}$ można podzielić na (2) karty debetowe oraz (3) karty kredytowe. Właśnie te trzy popularne instrumenty zostały wybrane do analizy w niniejszej pracy.

Obecnie na rynku polskim zdecydowanie dominują płatności gotówkowe. Wyniki wykorzystanego w pracy badania ankietowego wykazały, że 94,5\% wszystkich płatności klientów indywidualnych jest dokonywanych gotówka, a tylko 3,8\% kartami debetowymi i 1,7\% kartami kredytowymi. Podobne szacunki uzyskano w innych badaniach dotyczących Polski (Damińska, 2008). Dominacja płatności gotówkowych na rynku polskim jest rezultatem niskiego wykorzystania usług finansowych. W 2007 roku zaledwie 48\% polskiego społeczeństwa w wieku 15-75 lat posiadało konto bankowe, 35\% kartę debetowa a 8,2\% kartę kredytową (Polasik, Maciejewski, 2009). Ponadto nawet wśród posiadaczy kart płatniczych intensywność ich stosowania jest niewielka w porównaniu do płatności gotówkowych, co może wynikać z nawyków społeczeństwa oraz wciąż występujących w Polsce ograniczeń w sieci akceptacji kart.

Należy jednak podkreślić, że nawet w krajach o kilkudziesięcioletnim doświadczeniu klientów w posługiwaniu się kartami, np. w Stanach Zjednoczonych, Japonii czy Wielkiej Brytanii, gotówka wciąż pozostaje głównym środkiem płatności i obsługuje 65-95\% transakcji detalicznych. Do nielicznych wyjątków należą Norwegia, Finlandia czy Islandia (Damińska, 2008).

\section{MODELE ZMIENNYCH LICZNIKOWYCH}

Zmienna licznikowa przedstawia kategorię, której możliwe wartości są nieujemnymi liczbami całkowitymi. Stosowanie klasycznego modelu regresji liniowej w sytuacji, gdy zmienna endogeniczna jest zmienną licznikową może prowadzić do poważnych błędów poznawczych, szczególnie w przypadku gdy wartość oczekiwana zmiennej nie jest duża. Modele zmiennych licznikowych znalazły zastosowanie w wielu dziedzinach. Przeglądy prac dotyczące zastosowań ekonomicznych i finansowych przedstawiają między innymi Winkelmann (1997), Cameron i Trivedi (1998) oraz Gruszczyński (2002). Podstawowym modelem licznikowym jest model regresji Poissona, to jest model, w którym

\footnotetext{
${ }^{2} \mathrm{Z}$ punktu widzenia funkcjonalności karty kredytowe, w przeciwieństwie do debetowych, posiadają możliwość wykorzystania limitu kredytowego oraz mogą być stosowane w transakcjach zdalnych (np. w Internecie). Jednak ze względu na ryzyko kredytowe związane z posługiwaniem się kartą kredytową, są one trudniej dostępne dla klientów, którzy muszą spełnić określone wymogi oraz ponosić dodatkowe koszty.
} 
zmienna objaśniana $Y$ ma rozkład Poissona. Rozkład prawdopodobieństwa liczby zdarzeń $\mathrm{w}$ ustalonym okresie jest dany formułą:

$$
P\left(y_{i}=j\right)=\left(\lambda_{i}^{j} / j !\right) \exp \left(-\lambda_{i}\right) \quad j=0,1,2, \ldots
$$

Wartość oczekiwana jest określona jako:

$$
E\left[y_{i}\right]=\lambda_{i}=\exp \left(X_{i} \beta\right),
$$

gdzie $X_{i}$ jest wektorem zmiennych objaśniających o wymiarach $(1 \times k)$, a $\beta$ to wektor parametrów o wymiarach $(k \times 1)$.

Model regresji Poissona jest zazwyczaj punktem wyjścia analizy danych licznikowych. Dane empiryczne wykazują często odstępstwa od założeń tego modelu. W wielu zastosowaniach występuje na przykład nadmierna dyspersja i nie jest spełnione założenie o równości wartości oczekiwanej i wariancji rozkładu. Z tego względu w miejsce rozkładu Poissona przyjmuje się szereg innych rozkładów, najczęściej rozkład ujemny dwumianowy. Rozkład prawdopodobieństwa dla rozkładu ujemnego dwumianowego (NB) ma następującą postać:

$$
\begin{aligned}
& P\left(y_{i}=j\right)= \frac{\Gamma\left(y_{i}+\alpha^{-1}\right)}{\Gamma\left(y_{i}+1\right) \Gamma\left(\alpha^{-1}\right)}\left(\frac{\alpha^{-1}}{\alpha^{-1}+\lambda_{i}}\right)^{\alpha^{-1}}\left(\frac{\lambda_{i}}{\alpha^{-1}+\lambda_{i}}\right)^{y_{i}}, \\
& \alpha \geq 0, j=0,1,2, \ldots,
\end{aligned}
$$

gdzie $\Gamma(\cdot)$ oznacza funkcję gamma. Wartość oczekiwana rozkładu jest określona formułą (2), natomiast wariancja równa jest:

$$
\operatorname{Var}\left(y_{i}\right)=\lambda_{i}+\alpha \lambda_{i}^{2}
$$

i jest większa od wartości oczekiwanej. Jeżeli $\alpha=0$, to otrzymujemy model regresji Poissona. Parametr $\alpha$ bywa niekiedy nazywany parametrem dyspersji.

Inną często spotykaną w praktyce nie-Poissonowską cechą danych licznikowych jest nadmierny udział obserwacji z wartością zero (rzadziej inną wartością całkowitoliczbowa). Do opisu takich danych najczęściej stosuje się model płotkowy (ang. hurdle model) lub model zawyżonych zer (ZI model, ang. zero inflated model). $\mathrm{W}$ obu modelach odmiennie traktuje się jedną $\mathrm{z}$ wartości zmiennej, mianowicie $y=0$. Argumentuje się, iż jednostki, dla których obserwuje się $y=0$, stanowią znacząco różny zbiór $\mathrm{w}$ porównaniu z pozostałymi jednostkami obserwacji.

Model płotkowy Poissona został wprowadzony przez Mullahy'ego (1986). Ma on interpretację modelu dwuskładnikowego. Pierwszy składnik to model dwumianowy opisujący binarny wynik w postaci zera lub liczby dodatniej, drugi składnik to model licznikowy ucięty dla wartości zero opisujący wyniki dodatnie. Rozkład prawdopodobieństwa można zapisać w postaci: 


$$
\begin{aligned}
& P\left(y_{i}=0\right)=f_{1}(0), \\
& P\left(y_{i}=j\right)=f_{2}(j) \frac{1-f_{1}(0)}{1-f_{2}(0)}, \quad j=1,2, \ldots
\end{aligned}
$$

gdzie $f_{1}$ i $f_{2}$ oznaczają funkcje rozkładu prawdopodobieństwa.

Najczęściej stosowanymi modelami płotkowymi są modele o rozkładach Poissona i ujemnym dwumianowym.

Model ZI pozwala w nieco inny sposób opisać nadmierny udział obserwacji $\mathrm{z}$ wartością zero. Dla rozkładu Poissona model ten nazywany jest modelem ZIP (ang. zero inflated Poisson), natomiast dla rozkładu ujemnego dwumianowego modelem ZINB (ang. zero inflated negative binomial). Model ZIP można przedstawić w następującej postaci (patrz Cameron i Trivedi, 1998):

$$
\begin{aligned}
& P\left(y_{i}=0\right)=\varphi_{i}+\left(1-\varphi_{i}\right) e^{-\lambda_{i}}, \\
& P\left(y_{i}=j\right)=\left(1-\varphi_{i}\right) \frac{\exp \left(-\lambda_{i}\right) \lambda_{i}^{j}}{j !}, \quad j=1,2, \ldots
\end{aligned}
$$

Prawdopodobieństwo $\varphi_{i}$ może być dalej opisane na przykład jako funkcja logistyczna wektora parametrów $Z_{i}$. W pracy dalej przyjęto, że $Z_{i}=X_{i}$ oraz ${ }^{3}$ :

$$
\ln \left[\varphi_{i} /\left(1-\varphi_{i}\right)\right]=\tau X_{i} \beta,
$$

gdzie $\tau$ jest nazywane parametrem kształtu.

\section{WYNIKI EMPIRYCZNE}

Przeprowadzona analiza została oparta na wynikach badania ankietowego osób fizycznych, zapewniającego reprezentatywność próby dla populacji polskiego społeczeństwa w wieku 15-75 lat (Polasik, Maciejewski, 2009) ${ }^{4}$. Wszystkie dane obejmowały miesiąc wrzesień 2007 roku. Studia literatury przedmiotu oraz wcześniejsze badania autorów pozwoliły na określenie czynników, które potencjalnie mogą mieć wpływ na liczbę transakcji płatniczych dokonywanych przy użyciu trzech metod płatności wybranych do badania: (1) gotówki, (2) kart debetowych oraz (3) kart kredytowych. Dokonano podziału tych czynników na 6 grup: (a) czynniki demograficzne: płeć, wiek, wielkość miej-

\footnotetext{
${ }^{3}$ Patrz Lambert (1992) oraz Gilbert, Tourani-Rad i Wiśniewski (2006).

${ }^{4}$ Badanie ankietowe osób fizycznych zostało zrealizowane na zlecenie Narodowego Banku Polskiego. Badanie zostało przygotowane przez M. Polasika i K. Maciejewskiego, natomiast wywiady osobiste $\mathrm{z}$ respondentami przeprowadził instytut MillwardBrown SMG/KRC. Badanie zrealizowane zostało w październiku 2007 r. na 1010 osobowej reprezentatywnej próbie losowej. Ze względu na występujące odmowy odpowiedzi, do celów niniejszego badania wykorzystana została podpróba 583 osób, dla których odpowiedzi nie zawierały braków danych dla zmiennych objaśnianych i objaśniających.
} 
scowości, wykształcenie, dochody, sytuacja zawodowa i wielkość rodziny; (b) korzystanie z mediów telekomunikacyjnych: telefon stacjonarny i komórkowy, Internet; (c) dostęp do usług finansowych: konto bankowe tradycyjne i internetowe, karty płatnicze (rodzaje); (d) aktywność w zakresie usług finansowych: różne operacje bankowe i gotówkowe; (e) preferencje i opinie: stosunek do nowych technologii i problemu anonimowości, opinie nt. bezpieczeństwa operacji; (f) aktywność płatnicza: fakt dokonywania oraz liczba płatności wykonanych w poszczególnych typach punktów sprzedaży oraz w Internecie. Każdy z czynników mógł być opisany przez jedną lub większą liczbę zmiennych. Łącznie rozważano 38 potencjalnych zmiennych objaśniających ${ }^{5}$.

Średnie wartości płatności w miesiącu per capita wynosiły 16,20 dla gotówki, 0,65 dla karty debetowej oraz 0,29 dla karty kredytowej. W przypadku płatności kartami płatniczymi występowała nadmierna dyspersja. Odchylenie standardowe było ponad trzy i siedem razy większe od średniej arytmetycznej, odpowiednio dla karty debetowej i kredytowej (patrz tabele 3 i 4). Badane zmienne charakteryzowały się dużym bądź bardzo dużym udziałem obserwacji z wartością zero $(20,41 \%, 85,93 \%, 94,68 \%$ odpowiednio dla gotówki, karty debetowej oraz karty kredytowej).

Rozważano sześć specyfikacji modeli licznikowych przedstawionych w części trzeciej pracy: model regresji Poissona, model regresji NB, model płotkowy Poissona, model płotkowy ujemny dwumianowy, ZIP oraz ZINB. Estymacji parametrów dokonano metodą największej wiarygodności. Wyboru modelu dokonano na podstawie kryterium informacyjnego Schwarza (SIC) uwzględniając wyniki odpowiednich testów diagnostycznych. Wartości kryterium SIC dla badanych modeli zaprezentowano w tabeli 1.

Tabela 1. Wartości kryterium SIC dla modeli licznikowych

\begin{tabular}{cccc}
\hline & \multicolumn{3}{c}{ Metoda płatności } \\
\cline { 2 - 4 } Model regresji & Gotówka & Karta debetowa & Karta kredytowa \\
\hline Poissona & 5229,43 & 1094,16 & 771,83 \\
Ujemny dwumianowy & 3979,24 & 827,86 & 393,85 \\
Płotkowy Poissona & - & 829,94 & 447,10 \\
Płotkowy ujemny dwumianowy & - & 820,08 & 426,66 \\
ZIP & 4026,14 & 888,82 & 472,55 \\
ZINB & 3651,82 & 779,20 & 400,22 \\
\hline
\end{tabular}

Źródło: obliczenia własne.

Dla transakcji dokonywanych gotówką nie udało się uzyskać wiarygodnych szacunków parametrów dla modeli płotkowych. Według kryterium SIC najlepszym modelem dla transakcji dokonywanych przy użyciu gotówki i karty debe-

${ }^{5} \mathrm{Z}$ uwagi na ograniczony rozmiar publikacji nie możliwa jest szczegółowa prezentacja wszystkich zmiennych. 
towej jest model ZINB, natomiast przy użyciu karty kredytowej - model regresji ujemny dwumianowy. Dla wszystkich modeli i metod płatności wyraźnie lepsze dopasowanie uzyskiwano na podstawie rozkładu ujemnego dwumianowego.

Wyniki estymacji dla modelu ZINB dla płatności gotówką zostały przedstawione w tabeli 2, poniżej natomiast omówiono szacunki wybranych statystyk i miar, które miały wpływ na wybór ostatecznej parametryzacji modelu. Wyniki dotyczące regresji Poissona dla testu LR dotyczącego badania istotności łącznego wpływu zmiennych objaśniających $\left(\mathrm{LR}=5695,22^{6}(21,03)\right)$ oraz wartości współczynników pseudo- $\mathrm{R}^{2}$ opartych na statystyce odchylenia (ang. deviance statistics) oraz statystyce Pearsona ${ }^{7}$ równych odpowiednio $R_{D E V}^{2}=0,65$ i $R_{P}^{2}=0,66$ wskazują, że wybrane zmienne egzogeniczne stosunkowo dobrze jak na dane licznikowe wyjaśniają zmienność liczby transakcji gotówką ${ }^{8}$ Występowanie nadmiernej dyspersji można testować korzystając $\mathrm{z}$ wartości teoretycznych wyznaczonych z modelu regresji Poissona $\hat{\lambda}_{i}=\exp \left(X_{i} \hat{\beta}\right)$ i szacując za pomocą MNK równanie regresji:

$$
\left[\left(y_{i}-\hat{\lambda}_{i}\right)^{2}-y_{i}\right] / \hat{\lambda}_{i}=\alpha \hat{\lambda}_{i}+u_{i}
$$

gdzie $u_{i}$ jest to składnik losowy. Statystyka $t$ dla parametru $\alpha$ ma rozkład asymptotycznie normalny. Wartość $t=4,45(1,96)$ w przypadku modelu dla płatności gotówką pokazuje, że wariancja jest istotnie większa od średniej i występuje nadmierna dyspersja w postaci wynikającej z modelu NB ${ }^{9}$. Wynik testu Vuonga $(1989)^{10}$ (patrz tabela 2) wskazuje, że model ZINB lepiej niż model regresji NB opisuje liczbę transakcji gotówką.

Płatności gotówkowych dużo rzadziej dokonują mieszkańcy dużych miast, powyżej 500 tys. mieszkańców (przeciętnie mniej o 4,17 transakcji w miesią$\mathrm{cu}$ ). Wiek jest wprowadzony do równania $\ln \lambda_{i}=X_{i} \beta$ w postaci funkcji kwadratowej. Skłonność do płacenia gotówką spada wraz z wiekiem, jednak po przekroczeniu 47 lat zaczyna ponownie wzrastać. Liczba płatności gotówką wzrasta także wraz ze wzrostem dochodu netto oraz liczbą osób w gospodarstwie domowym, co wynika z większych możliwości i potrzeb płatniczych. Osoby zlecające przelewy w oddziale bankowym, a więc preferujący bezpośredni kontakt z pracownikami banku, dokonują w miesiącu przeciętnie aż

\footnotetext{
${ }^{6} \mathrm{~W}$ pracy w nawiasach podano wartości krytyczne dla poziomu istotności 0,05 .

${ }^{7}$ Konstrukcja stosowanych statystyk i miar dopasowania została przedstawiona w pracy Cameron i Trivedi, 1998.

${ }^{8}$ Dla danych licznikowych relatywnie trudniej uzyskać model o wysokim dopasowaniu do danych empirycznych.

${ }^{9}$ Taki sam wniosek uzyskano na podstawie testu LR $(\mathrm{LR}=1256,55(3,84))$.

${ }^{10}$ Vuong zaproponował statystykę, na podstawie której można dokonać wyboru między modelami niezagnieżdżonymi ZIP i regresji Poissona (lub między ZINB i NB). Statystyka ma asymptotyczny rozkład normalny (wartość krytyczna dla 0,05 wynosi 1,96). Wartość statystyki większa od wartości krytycznej sugeruje wybór modelu ZI.
} 
o 5,19 płatności gotówką więcej. Wiąże się to zapewne z faktem, iż częstość płacenia gotówką wzrasta wraz z przekonaniem danej osoby, że nowoczesne technologie teleinformatyczne mają charakter elitarny i nie są użyteczne dla wszystkich. Silnie stymulujący wpływ na płatności gotówkowe ma aktywność klientów w zakresie dokonywania płatności w małych sklepach spożywczych, supermarketach, sklepach z artykułami przemysłowymi oraz w środkach transportu publicznego. Wyniki potwierdziły fakt, że płatności gotówkowe są substytucyjne wobec płatności kartą. Przeprowadzone badanie pokazało również, że bardzo trudno jest wyjaśnić zmienność liczby transakcji gotówką bez uwzględnienia liczby transakcji w poszczególnych punktach sprzedaży.

Tabela 2. Model ZINB dla liczby transakcji dokonanych gotówką

\begin{tabular}{ccccc}
\hline Zmienna & Ocena par. & Błąd oceny & Stat. t & Efekt krańcowy \\
\hline Stała & 1,9758 & 0,1622 & 12,18 & 34,6619 \\
Mieszkaniec dużego miasta (zmienna 0-1) & $-0,2378$ & 0,0742 & $-3,20$ & $-4,1723$ \\
Wiek (lata) & $-0,0197$ & 0,0077 & $-2,57$ & $-0,3455$ \\
Wiek do kwadratu & $2,1122 \mathrm{e}-4$ & $0,9052 \mathrm{e}-4$ & 2,33 & 0,0037 \\
Dochód netto (w PLN) & $0,5712 \mathrm{e}-4$ & $0,1696 \mathrm{e}-4$ & 3,37 & 0,0010 \\
Wielkość gospodarstwa (liczba osób) & 0,0338 & 0,0152 & 2,22 & 0,5922 \\
Nowe technologie sa elitarne (skala 1-5) & 0,0416 & 0,0193 & 2,16 & 0,7297 \\
Zlecał przelew w oddziale banku (0-1) & 0,2957 & 0,0738 & 4,01 & 5,1871 \\
Liczba transakcji - supermarket & 0,0534 & 0,0038 & 13,91 & 0,9371 \\
Liczba transakcji - sklepy spożywcze & 0,0554 & 0,0015 & 36,84 & 0,9714 \\
Liczba transakcji - artykuły przemysłowe & 0,0448 & 0,0062 & 7,22 & 0,7859 \\
Liczba transakcji - transport publiczny & 0,0485 & 0,0060 & 8,12 & 0,8507 \\
Liczba transakcji karta debetowa & $-0,0308$ & 0,0077 & $-4,00$ & $-0,5395$ \\
Parametr dyspersji $\alpha$ & 0,0981 & 0,0130 & 7,54 & - \\
Parametr $\tau$ & $-0,6592$ & 0,0602 & $-10,95$ & - \\
\hline \multicolumn{1}{c}{ S(y) = 14,92 } & Funkcja wiaryg. $=-1781,33$ & Stat Vuonga $=8,64$ \\
\hline $\bar{y}=16,20$ & \multicolumn{4}{c}{}
\end{tabular}

Źródło: obliczenia własne.

Wyniki testów i miar dopasowania dla płatności kartą debetową dla regresji Poissona wskazuja, że wybrane zmienne egzogeniczne relatywnie dobrze wyjaśniają zmienność liczby płatności ${ }^{11}\left(\mathrm{LR}=961,07(22,36), R_{D E V}^{2}=0,56\right.$, $\left.R_{P}^{2}=0,68\right)$. Wartość statystyki $t=3,02(1,96)$ dla testu nadmiernej dyspersji wskazuje, że wariancja jest istotnie większa od średniej i niewłaściwe jest stosowanie rozkładu Poissona ${ }^{12}$. Wynik testu Vuonga (1989) wskazuje, że model ZINB lepiej opisuje liczbę transakcji gotówką niż model regresji NB. Wyniki estymacji dla modelu ZINB zostały przedstawione w tabeli 3.

Wykorzystanie kart debetowych jest znacznie niższe wśród mieszkańców wsi. Liczba transakcji wzrasta wraz z wiekiem, jednak po przekroczeniu 46 lat zaczyna się obniżać, ponieważ osoby starsze są mniej skłonne do używania kart

\footnotetext{
${ }^{11}$ Zastosowano te same testy i miary co w analizie płatności gotówką.

${ }^{12}$ Ten wniosek jest zbieżny $z$ rezultatami testu LR $(\operatorname{LR}=272,66(3,84))$.
} 
płatniczych lub ich nie posiadają. Istotny negatywny wpływ posiada też niski dochód respondenta, natomiast pozytywnie wpływa fakt korzystania z mediów telekomunikacyjnych: telefonu stacjonarnego oraz Internetu. Fakt dokonywania przelewów bankowych istotnie zwiększa liczbę płatności tą metodą - przeciętnie o 0,64 transakcji w miesiącu. Stymulująco na płatności kartą debetową wpływa częste korzystanie ze stacji benzynowych, które są w Polsce, obok supermarketów, głównymi akceptantami płatności kartowych. Widoczny jest efekt substytucyjny pomiędzy kartą debetową i gotówką. Znacznie silniejsza jest jednak substytucja między kartą debetową i kredytową.

Tabela 3. Model ZINB dla liczby transakcji dokonanych kartą debetową

\begin{tabular}{ccccc}
\hline Zmienna & Ocena par. & Błąd oceny & Stat. t & $\begin{array}{c}\text { Efekt krań- } \\
\text { cowy }\end{array}$ \\
\hline Stała & $-2,7040$ & 0,9041 & $-2,99$ & $-2,5731$ \\
Mieszkaniec wsi (0-1) & $-0,7876$ & 0,2191 & $-3,59$ & $-0,7495$ \\
Wiek (lata) & 0,0865 & 0,0320 & 2,70 & 0,0823 \\
Wiek do kwadratu & $-0,0010$ & 0,0004 & $-2,58$ & $-0,0009$ \\
Poziom wykształcenia (skala 1-9) & 0,0758 & 0,0363 & 2,09 & 0,0721 \\
Dochód minimalny - poniżej 800 PLN (0-1) & $-0,3187$ & 0,1456 & $-2,19$ & $-0,3033$ \\
Telefon stacjonarny (0-1) & 0,3521 & 0,1366 & 2,58 & 0,3351 \\
Korzystanie z Internetu (0-1) & 0,3835 & 0,1534 & 2,50 & 0,3649 \\
Zlecony przelew bankowy (0-1) & 0,6707 & 0,1850 & 3,63 & 0,6382 \\
Preferowanie anonimowości (skala 1-5) & $-0,1237$ & 0,0568 & $-2,18$ & $-0,1177$ \\
Bezpieczeństwo płacenia karta (skala 1-5) & 0,2216 & 0,0752 & 2,95 & 0,2109 \\
Liczba transakcji - stacje benzynowe & 0,1068 & 0,0288 & 3,70 & 0,1017 \\
Liczba transakcji gotówka & $-0,0072$ & 0,0042 & $-1,69$ & $-0,0068$ \\
Liczba transakcji karta kredytowa & $-0,2183$ & 0,0887 & $-2,46$ & $-0,2077$ \\
Parametr dyspersji $\alpha$ & 1,7878 & 0,2200 & 8,13 & - \\
Parametr $\tau$ & $-3,0403$ & 1,0866 & $-2,80$ & - \\
\hline \multicolumn{1}{c}{ S(y) $=2,19$} & Funkcja wiaryg. $=-341,84$ & Stat. Vuonga $=4,55$ \\
\hline
\end{tabular}

Źródło: obliczenia własne.

Uzyskane wyniki pokazują także, że na skłonność do dokonywania płatności kartami silnie wpływa poczucie bezpieczeństwa klientów. Wzrost oceny bezpieczeństwa o 1 kategorię (w skali 5-cio punktowej) powoduje przeciętnie wzrost liczby płatności kartą debetową o 0,21 transakcji. Natomiast istotny negatywny wpływ na intensywność korzystania z kart debetowych ma preferowanie przez klienta anonimowości dokonywania płatności. Jest to uzasadnione, ponieważ podczas płatności kartą debetową czy kredytową klient traci swoją anonimowość w stosunku do sprzedawcy w punkcie handlowym, ale przede wszystkim następuje rejestracja wszystkich dokonanych w ten sposób transakcji w systemie bankowym, co pozwala na śledzenie zachowania klienta. Osoby obawiające się o utratę prywatności mogą zatem świadomie rezygnować z płacenia kartami.

Wyniki estymacji dla modelu regresji ujemnego dwumianowego dla płatności kartą kredytową zostały przedstawione $\mathrm{w}$ tabeli 4 , poniżej omówiono szacunki wybranych statystyk i miar, które miały wpływ na wybór ostatecznej pa- 
rametryzacji modelu. Zmienne objaśniające stosunkowo dobrze wyjaśniaja zmienność liczby płatności kartą $\left(\mathrm{LR}=562,51 \quad(15,51), \quad R_{D E V}^{2}=0,47\right.$, $\left.R_{P}^{2}=0,78\right)$. Wartość statystyki $t=6,23(1,96)$ dla testu nadmiernej dyspersji wskazuje, że wariancja jest istotnie większa od średniej i niewłaściwe jest stosowanie rozkładu Poissona ${ }^{13}$. Wynik testu Vuonga (1989) wskazuje, że nie jest celowe stosowanie do opisu tej zmiennej modelu ZINB.

Tabela 4. Model regresji NB dla liczby transakcji dokonanych kartą kredytową

\begin{tabular}{ccccc}
\hline Zmienna & Ocena par. & Błąd oceny & Stat. t & Efekt krańcowy \\
\hline Stała & $-11,9904$ & 2,5884 & $-4,63$ & $-5,5627$ \\
Wielkość miejscowości (skala 1-4) & 1,2163 & 0,2926 & 4,16 & 0,5643 \\
Wyższe wykształcenie (skala 1-9) & 1,2086 & 0,6973 & 1,73 & 0,5607 \\
Stała praca (0-1) & 2,0141 & 0,5821 & 3,46 & 0,9344 \\
Internetowe konto bankowe (0-1) & 1,8637 & 0,6471 & 2,88 & 0,8646 \\
Prostota użycia telefonu komórk. (skala 1-5) & 0,7111 & 0,3416 & 2,08 & 0,3299 \\
Preferowanie anonimowości (skala 1-5) & $-0,4054$ & 0,2346 & $-1,73$ & $-0,1881$ \\
Bezpieczeństwo płacenia karta (skala 1-5) & 1,0171 & 0,4177 & 2,44 & 0,4718 \\
Liczba transakcji kartą debetową & $-0,4290$ & 0,1798 & $-2,39$ & $-0,1990$ \\
Parametr dyspersji $\alpha$ & 13,6150 & 3,4696 & 3,92 & - \\
\hline$\quad$ S(y) =2,05 & Funkcja wiaryg. $=-168,27$ & Stat. Vuonga $=0,61$ \\
\hline$y=0,29$
\end{tabular}

Źródło: obliczenia własne.

Płatności kartami kredytowymi są znacznie częściej dokonywane przez mieszkańców większych miejscowości oraz osoby o wyższym poziomie wykształcenia. Bardzo ważnym czynnikiem jest $\mathrm{w}$ ich przypadku posiadanie stałej pracy, które zwiększa przeciętną liczbę transakcji o $0,93 \mathrm{w}$ miesiącu. Wynika to z faktu, że wydanie klientowi karty kredytowej jest zazwyczaj związane z koniecznością udokumentowania zatrudnienia lub dochodów. Częściej używają kart kredytowych także posiadacze internetowych kont bankowych oraz osoby uważające obsługę telefonów komórkowych za prostą, a więc obeznane z nowymi technologiami. Wyniki potwierdziły ponadto istnienie substytucji transakcji dokonywanych kartą kredytową i kartą debetową. W przypadku karty kredytowej obserwowany jest analogiczny jak dla karty debetowej wpływ poczucia bezpieczeństwa i stosunku klientów do anonimowości płatności.

Duża liczba czynników demograficznych wpływających na liczbę transakcji dokonywanych badanymi metodami płatności wskazuje, że nie można odrzucić hipotezy H1. Uzyskane wyniki potwierdzają także hipotezę H2, dotycząca wpływu poczucia bezpieczeństwa i problemu anonimowości na korzystanie z kart płatniczych. Ponadto wyniki sugerują, że poszczególne rodzaje punktów handlowych mają wpływ na intensywność stosowania różnych metod płatności, jednak jednoznaczna weryfikacja hipotezy H3 nie jest możliwa w oparciu

\footnotetext{
${ }^{13}$ Ten wniosek jest zbieżny z rezultatami testu LR $(\operatorname{LR}=384,35(3,84))$.
} 
o uzyskane wyniki. Zatem określenie dokładnego wpływu typów punktów sprzedaży na te metody wymaga przeprowadzenia dodatkowych badań.

\section{PODSUMOWANIE I WNIOSKI}

Wyniki przeprowadzonego badania wykazały, że na liczbę transakcji płatniczych dokonywanych przez klientów poszczególnymi metodami ma wpływ bardzo wiele zróżnicowanych czynników. Generalnie gotówkę preferują osoby zamieszkałe na wsi i w mniejszych miastach, osoby starsze oraz bardzo młode i osoby traktujące nowe technologie z duża ostrożnością. $Z$ kolei więcej płatności kartami debetowymi i kredytowymi dokonują osoby o wyższym poziomie wykształcenia, mieszkające w większych miejscowościach, posiadające stałe zarobki oraz powszechnie korzystające z mediów telekomunikacyjnych. Istotnym bodźcem jest także korzystanie $\mathrm{z}$ usług bankowych. Widoczny jest efekt substytucyjny pomiędzy płatnościami dokonywanymi kartami debetowymi i kredytowymi.

Bardzo silny wpływ poczucia bezpieczeństwa na wykorzystanie kart do płatności w punktach handlowych wskazuje, z jednej strony na potrzebę powszechnej edukacji klientów w tym zakresie, a z drugiej na konieczność realnego zwiększania bezpieczeństwa, co ma obecnie miejsce w ramach migracji kart płatniczych oraz terminali i bankomatów do standardu kart mikroprocesorowych EMV (Polasik, Maciejewski, 2009). Ponoszenie nakładów na bezpieczeństwo przez banki i agentów rozliczeniowych jest zatem niezbędne dla uzyskania radykalnego zwiększenia liczby płatności kartami.

Okazuje się ponadto, że istotną barierą dla rozwoju płatności kartowych są preferencje społeczeństwa dla zachowania anonimowość realizacji płatności. Stoją one w sprzeczności z działaniami instytucji publicznych na rzecz wykorzystania obrotu bezgotówkowego w celu zwiększenia kontroli nad firmami oraz osobami fizycznymi (Brits, Winder, 2005). Jest to uzasadniane koniecznością ograniczenia tzw. szarej strefy i walką z przestępczością, jednak może spotkać się z oporem znacznych grup społeczeństwa.

\section{LITERATURA}

Bolt W., Humphrey D. (2007), Payment Network Scale Economies, SEPA, and Cash Replacement, ,Review of Network Economics”, 6 (4), 453-473.

Bolt W., Jonker N., Van Renselaar C. (2008), Incentives at the Counter: An Empirical Analysis of Surcharging Card Payments and Payment Behaviour in the Netherlands, DNB Working, De Nederlandsche Bank, Paper, No. 196 / December, 1-34.

Borzekowski R., Kiser E.K. (2008), The Choice at the Checkout: Quantifying Demand Across Payment Instruments, „International Journal of Industrial Organization”, 26, 889-902.

Cameron A. C., Trivedi P. K. (1998), Regression Analysis of Count Data, Cambridge University Press, Cambridge.

Chakravorti S., Roson R. (2006), Platform Competition in Two-Sided Markets: The Case of Payment Networks, „Review of Network Economics”, 5 (1), 118-143. 
Damińska A., (2008) red. Obrót bezgotówkowy - zalety i korzyści wynikajace z jego upowszechnienia, Narodowy Bank Polski, Departament Systemu Płatniczego, Warszawa.

Gilbert A., Tourani-Rad A., Wisniewski T. P. (2006), Do Insiders Crowd out Analysts?, „Finance Research Letters", 3, 40-48.

Gresvik O., Haare H. (2009), Costs in the Norwegian Payment System, Norges Bank, Working paper, No 4.

Gruszczyński M. (2002), Modele i prognozy zmiennych jakościowych w finansach i bankowości, SGH, Warszawa.

Lambert D. (1992), Zero-Inflated Poisson Regression with an Application to Defects in Manufacturing, ,Technometrics”, 34, 1-14.

Leinonen H. (2008), Payment Habits and Trends in the Changing E-landscape 2010+, Expository Studies, Bank of Finland, A: 111.

Levitin A. J. (2007), Payment Wars: The Merchant-Bank Struggle for Control of Payment Systems, „Stanford Journal of Law, Business \& Finance”, 12 (2), 1-66.

Mullahy J. (1986), Specification and Testing in Some Modified Count Data Models, „Journal of Econometrics", 33, 341-365.

Polasik M., Maciejewski K. (2009), Innowacyjne ustugi platnicze w Polsce i na świecie, „Materiały i Studia", Narodowy Bank Polski, Warszawa (w druku).

Polasik M., Fiszeder P. (2009), Factors Determining the Acceptance of Payment Methods by Online Shops in Poland, Working Paper Series, European Central Bank (w druku).

Rochet J.-C., Tirole J. (2003), Platform Competition in Two-Sided Markets, „Journal of the European Economic Association", 1 (4), 990-1029.

Vuong Q. (1989), Likelihood Ratio Tests for Model Selection and Non-Nested Hypotheses, „Econometrica”, 57, 307-334.

Winkelmann R. (1997), Econometric Analysis of Count Data, Springer-Verlag, Berlin Heidelberg.

\section{MODELING THE NUMBER OF TRANSACTIONS USING CASH AND PAYMENT CARDS ON THE POLISH MARKET}

A b s t r a c t. The work deals with an analysis of factors determining the intensity of usage of payment methods by Polish customers. The study covers the 3 main payment methods used in physical Points-of-Sale: cash, debit cards and credit cards. In order to describe the number of payments count data models: Poisson regression, negative binomial regression, Poisson hurdle model, negative binomial hurdle model, ZIP and ZINB were applied. The results obtained in the study revealed a significant effect of many demographic factors, as well as the use of financial and telecommunication services. A substitution effect between payments by credit and debit cards has been shown. The study demonstrated a strong impact of customers' concerns about security on the usage of cards. A significant barrier to the development of card payments are also the preferences of society for maintaining the anonymity of payment transactions.

K e y w o r d s: payment methods, payment cards, cashless turnover, count data models. 